\title{
PELATIHAN DAN PENDAMPINGAN PENULISAN KARYA TULIS ILMIAH UNTUK GURU DI INDONESIA
}

\author{
MUHAMAD SUHARDI ${ }^{1}$, I MADE SONNY GUNAWAN ${ }^{2}$ \\ ${ }^{1}$ Administrasi Pendidikan, FIPP Universitas Pendidikan Mandalika \\ ${ }^{2}$ Bimbingan Konseling, FIPP Universitas Pendidikan Mandalika \\ Email: ardhysmart7@gmail.com
}

\begin{abstract}
ABSTRAK
Menyusun karya tulis ilmiah merupakan salah satu tuntutan profesi bagi seorang guru. Permasalahannya adalah tidak semua guru memiliki kemampuan dalam menyusun karya tulis ilmiah dengan baik, salah satunya yang berbentuk artikel ilmiah. Berdasarkan studi pendahuluan terhadap guru di Indonesia, dapat diketahui bahwa sebagian besar guru masih mengalami kesulitan dalam menyusun artikel ilmiah. Berawal dari permasalahan tersebut perlu dilakukan pelatihan dan pendampingan dalam penulisan artikel bagi para guru. Program pelatihan dan pendampingan didesain dalam bentuk kegiatan pengabdian masyarakat. Kegiatan pengabdian tersebut dilakukan oleh Guru Inovatif Indonesia. Kegiatan pelatihan dan pendampingan dilakukan dengan metode blended, yaitu melalui tatap muka dan melalui daring. Tahapan pertama merupakan pelatihan yang mencakup teori dan praktik sedangkan tahap kedua adalah bimbingan dalam melakukan publikasi artikel pada jurnal ilmiah. Hasil dari kegiatan pengabdian masyarakat ini adalah dapat menambah wawasan dan keterampilan guru dalam menulis karya tulis ilmiah. Selain itu guru dapat melakukan publikasi artikel pada jurnal ilmiah secara mandiri sebagai salah satu tuntutan profesi sebagai seorang guru.
\end{abstract}

Kata Kunci : Pelatihan Dan Pendampingan, Karya Tulis Ilmiah

\section{PENDAHULUAN}

Menyusun Karya Tulis Ilmiah (KTI) merupakan salah satu bentuk dari kegiatan pengembangan profesi guru. Keprofesionalan seorang guru tidak terjadi secara otomatis, tetapi akan semakin meningkat secara bertahap dengan didasarkan atas kemampuan dan kemauan guru di dalam meningkatkan profesionalisme (Ermiana, Affandi, \& Kusuma, 2019). Pengembangan profesi terdiri dari lima macam kegiatan, yaitu: menyusun karya tulis ilmiah, menemukan teknologi tepat guna, membuat alat peraga/bimbingan, menciptakan karya seni, dan mengikuti kegiatan pengembangan kurikulum. Sebagai salah satu pengembangan profesi, guru diharapkan mampu menyusun karya tulis ilmiah. Kemampuan menulis bagi guru sangat penting karena menjadi tuntutan profesi (Mujianto, Zubaidi, \& Suprapto, 2017). Bagi pengembangan karir dan untuk tetap belajar, guru wajib memenuhi syarat menulis karya ilmiah. Syarat ini seringkali menjadi penghambat kenaikan jenjang pangkat bagi guru mengingat rendahnya kemampuan dan minat menulis di kalangan guru. Sementara kemampuan menulis merupakan kemampuan dasar yang penting untuk dikuasai (Widiastuti, 2019).

Aktivitas menulis karya ilmiah selain menjadi syarat bagi pengembangan karir, menulis juga menjadi sarana bagi pengembangan diri seorang guru (Siregar \& Harahap, 2019). Guru memiliki banyak potensi dan potensi yang dimilikinya akan berkembang secara optimal dengan menulis (Cahyani, 2010). Hal ini didukung oleh banyaknya kondisi guru yang memperkuat peluang berkembangnya kemampuan menulis. Pertama, guru selalu berinteraksi dengan ilmu pengetahuan yang dapat menjadi bahan untuk menulis. Kedua, guru selalu berinteraksi dengan siswa saat kegiatan pembelajaran di kelas yang dapat dijadikan sumber tulisan. Ketiga, guru sering berinteraksi dengan dunia pendidikan dan kebijakannya yang dinamis, selalu menuntut untuk berpikir kritis, mengeluarkan ide-ide inovatif. Keempat, banyak peluang lomba menulis, baik yang diselenggarakan Dinas Pendidikan maupun Departemen Agama sebagai instansi yang menaunginya. Kelima, media masa menyediakan banyak rubrik pendidikan yang memungkinkan bagi guru untuk mengekspresikan gagasan-gagasannya. Peluang guru untuk 
menulis sangat banyak, akan tetapi peluang-peluang tersebut belum banyak dimanfaatkan oleh para guru (Gereda, 2014).

Keluhan tidak dapat menulis masih saja menjadi hambatan bagi guru untuk menangkap peluang tersebut, sehingga pengembangan diri dan karirnya berjalan tidak seperti yang diharapkan. Bahkan, keluhan menulis di kalangan guru tentu saja tanpa sebab. Secara umum ada beberapa kendala yang dapat ditemukan sehingga membuat tingkat partisipasi menulis dikalangan guru rendah. Kendala tersebut yaitu: pertama, rendahnya minat membaca dan menulis. Aktivitas menulis tidak dilepaskan dari aktivitas membaca (Widodo, Indraswasti, Erfan, Maulyda, \& Rahmatih, 2020). Selama ini guru lebih banyak disibukkan dengan aktivitas mengajar di kelas sehingga kewajiban membaca untuk pengembangan dirinya menjadi tidak terpenuhi. Kedua, keterbatasan kesediaan bahan bacaan yang bisa menjadi bahan tulisan. Ketiga, tidak adanya rasa percaya diri dan kurangnya pengalaman untuk menulis. Kelima, rendahnya motivasi menulis.

Kondisi semacam inilah yang terjadi seluruh daerah di Indonesia. Maka dari itu tim Guru Inovatif merasa perlu melaksanakan pengabdian masyarakat yang berupa pelatihan dan pendampingan menulis karya ilmiah. Berdasarkan studi pendahuluan dapat diketahui bahwa para guru di sekolah mitra belum memiliki pengetahuan yang cukup terkait dengan penulisan karya tulis ilmiah. Padahal wawasan tentang penulisan karya tulis ilmiah sangat dibutuhkan oleh guru sebagai syarat kenaikan jabatan dan pengembangan diri. Dari hasil wawancara, guru hanya disibukkan dan fokus terhadap proses belajar mengajar saja. Selain itu para guru merasa kesulitan dalam menemukan ide untuk menulis karya ilmiah. Padahal dari proses belajar mengajar di kelas dapat dijadikan sebuah ide dan peluang untuk menulis karya tulis ilmiah sesuai dengan permasalahan yang ditemukan.

Melihat permasalahan dilapangan kemampuan menulis karya ilmiah, maka prioritas yang disepakati untuk diselesaikan selama pelaksanaan program pengabdian masyarakat di seluruh Indonesai adalah meningkatkan kemampuan menulis karya ilmiah, khususnya artikel ilmiah pada guru- guru. Untuk meningkatkan kemampuan menulis guru tersebut, maka tim Guru Inovatif Indonesia mengadakan pelatihan dan pendampingan penulisan karya tulis ilmiah pada sekolah mitra. Untuk menyelesaikan permasalahan yang dihadapi guru-guru sekolah mitra, maka akan diadakan kegiatan pengabdian tentang pelatihan dan pendampingan penulisan karya tulis ilmiah. Dengan adanya pelatihan dan pendampingan tersebut, diharapkan agar guru-guru dapat termotivasi dan mau memulai menulis karya ilmiah sesuai dengan masalah yang sedang dialami terkait proses pembelajaran di dalam kelas. Oleh karena itu, materi pelatihan meliputi beberapa hal berikut yaitu: 1) membuat karya tulis ilmiah dan sistematikanya, 2) kaidah penulisan artikel ilmiah sesuai dengan kaidah bahasa Indonesia yang baik dan benar, 3) strategi menemukan sumber referensi yang sesuai dengan kaidah tulisan ilmiah, dan 4) praktik membuat karya tulis ilmiah.

\section{METODE PELAKSANAAN}

Kegiatan ini akan direncanakan dalam dua tahap, yaitu tahap pertama tentang pelatihan menulis karya ilmiah. Tahap ini dibagi menjadi empat sesi, sesuai dengan desain materi pelatihan. Peserta dilatih untuk menulis artikel ilmiah sesuai dengan kaidah bahasa Indonesia yang baik dan benar, serta dibekali keterampilan untuk menemukan sumber referensi yang kredibel. Langkah- langkah pada tahap ini adalah sebagai berikut:

1. Penyampaian materi tentang membuat tulisan ilmiah dan sistematikanya.

2. Penyampaian materi tentang kaidah penulisan artikel ilmiah sesuai dengan kaidah bahasa Indonesia yang baik dan benar.

3. Penyampaian materi tentang strategi menemukan sumber referensi yang sesuai kaidah tulisan ilmiah.

4. Praktek membuat tulisan ilmiah dipandu oleh dosen pendamping.

Tahap kedua merupakan tahap pendampingan. Pada tahap kedua guru didampingi dalam praktik penulisan karya ilmiah. Jenis karya tulis ilmiah yang dimaksud berupa artikel. Artikel 
dapat dikembangkan dari laporan PTK atau jenis penelitian lain yang telah dimiliki oleh guru. Pada tahap akhir guru juga dibimbing untuk mempublikasikan artikel pada jurnal ilmiah. Setelah program pengabdian masyarakat ini diharapkan guru dapat menulis dan mempublikasikan artikel secara mandiri pada jurnal ilmiah.

Metode pelaksanaan pengabdian masyarakat dilakukan dengan model tatap muka dan model daring. Berdasarkan hasil kesepakatan dengan guru-guru se Indonesia maka guru yang bersedia mengikuti kegiatan pengabdian secara daring melalui zoom meeting. Model semacam ini dilakukan mengingat pandemi Covid-19 belum berakhir, sehingga kerumunan massa sedapat mungkin harus dihindari. Maka dari itu pengabdian masyarakat didesain dalam bentuk kelas virtual untuk guru-guru se Indonesia.

\section{HASIL DAN PEMBAHASAN}

Peserta kegiatan pengabdian kepada masyarakat dalam pelatihan dan pendampingan penulisan karya tulis ilmiah adalah para guru se Indonesia. Jumlah keseluruhan guru yang mengikuti program pengabdian masyarakat sejumlah 300 orang. Dikarenakan program pengabdian masyarakat dilakukan di tengah pandemi Covid-19 maka pelaksanaan kegiatan dilakukan secara daring.

Hari pertama yang disampaikan berkaitan dengan mencari ide dan konsep dari suatu penelitian serta dasar-dasar membuat tulisan ilmiah. Pada materi ini diulas secara tuntas tentang jenis karya tulis ilmiah, namun titik berat dalam materi pengabdian ini adalah karya tulis yang berupa artikel ilmiah. Pemateri pertama tidak lupa menyampaikan sistematika artikel ilmiah yang telah lazim digunakan sesuai dengan standar jurnal ilmiah bereputasi.

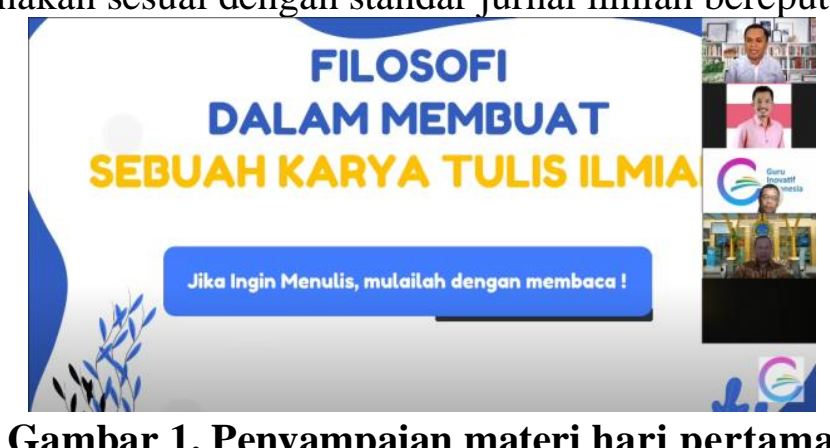

Gambar 1. Penyampaian materi hari pertama

Hari kedua menyampaikan materi tentang kaidah penulisan artikel ilmiah sesuai dengan kaidah bahasa Indonesia yang baik dan benar. Materi ini penting disampaikan mengingat para guru sering terjebak dalam penggunaan bahasa yang salah pada karya tulis ilmiah. Sebagian besar guru tidak mampu membedakan ragam bahasa baku/tidak baku, ragam bahasa tulis/lisan dan ragam bahasa lainnya. Selain itu kemampuan guru dalam membuat kalimat efektif masih kurang. Kemampuan menulis kalimat yang sesuai dengan kaidah juga tidak jauh berbeda. Akibatnya kalimat yag dibuat cenderung ambigu. Maka dari itu aspek bahasa sangat penting disampaikan kepada para guru sebagai bekal dalam penulisan karya ilmiah.

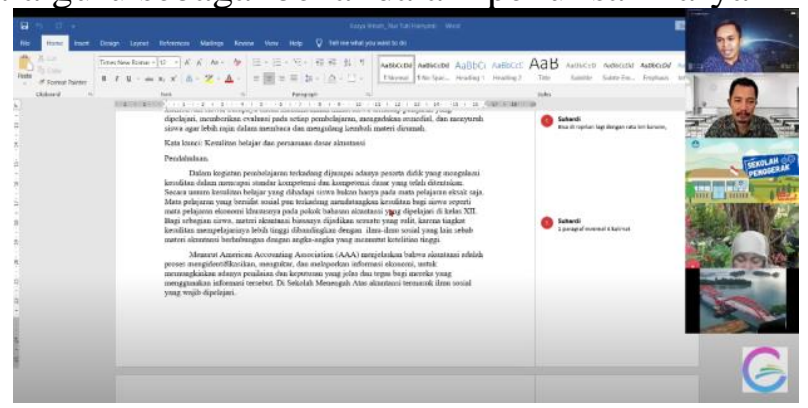

Gambar 2. Penyampaian materi hari kedua

Hari ketiga menyampaikan materi tentang strategi menemukan sumber referensi dan teknik pengutipan yang sesuai kaidah tulisan ilmiah. Tidak dapat dipungkiri bahwa referensi 


\section{COMMUNITY : Jurnal Pengabdian Kepada Masyarakat Vol. 1 No. 1 Mei 2021 e-ISSSN : 2797-0159 | p-ISSN : 2797-0574}

memiliki peranan yang sangat penting dalam penulisan karya ilmiah. Salah satu indikator karya tulis yang berkualitas dapat terlihat dari referensi yang digunakan. Namun demikian tidak banyak para guru yang memiliki pengetahuan tentang pentingnya referensi dalam penulisan karya ilmiah. Hal ini dapat terlihat dari banyaknya karya guru yang menggunakan website tidak kredibel sebagai bahan rujukan. Maka dari itu para guru perlu diberi bekal pengetahuan bagaimana mencari, memilih dan memilah sumber referensi yang valid sebagai bahan rujukan. Materi terakhir yang disampaikan adalah teknik publikasi pada jurnal ilmiah bereputasi. Teknik publikasi merupakan tahapan terpenting dalam rangkaian penulisan karya ilmiah. Karena sebaik apapun sebuah karya ilmiah jika tidak dipublikasikan tidak akan berguna. Maka dari itu para guru diberi pengetahuan agar memiliki kemampuan dalam melakukan publikasi pada jurnal ilmiah.

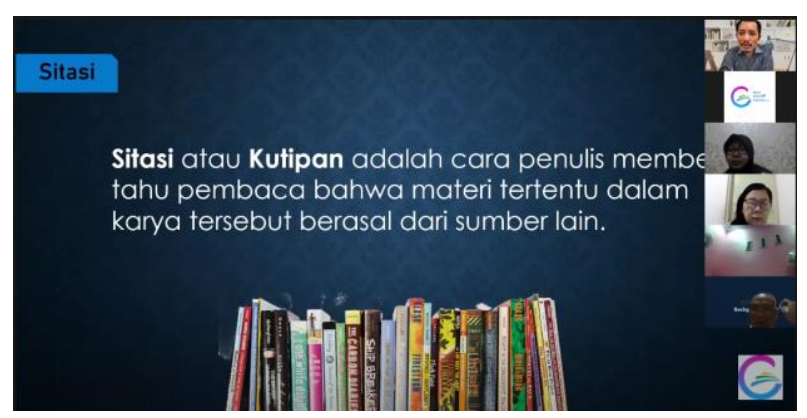

Gambar 3. Penyampaian materi hari ketiga

Setelah tahap penyampaian materi selesai dilakukan, tahapan selanjutnya adalah pendampingan. Pendampingan pertama berkaitan dengan praktik penulisan artikel ilmiah dan kedua berkaitan dengan praktik publikasi pada jurnal ilmiah. Praktik penulisan dengan memanfaatkan laporan PTK maupun laporan penelitian yang telah dimiliki oleh para guru. Sebelum kegiatan pelatihan diharapkan para guru mempersiapkan laporan penelitian terdahulu sebagai bahan pembuatan artikel ilmiah.

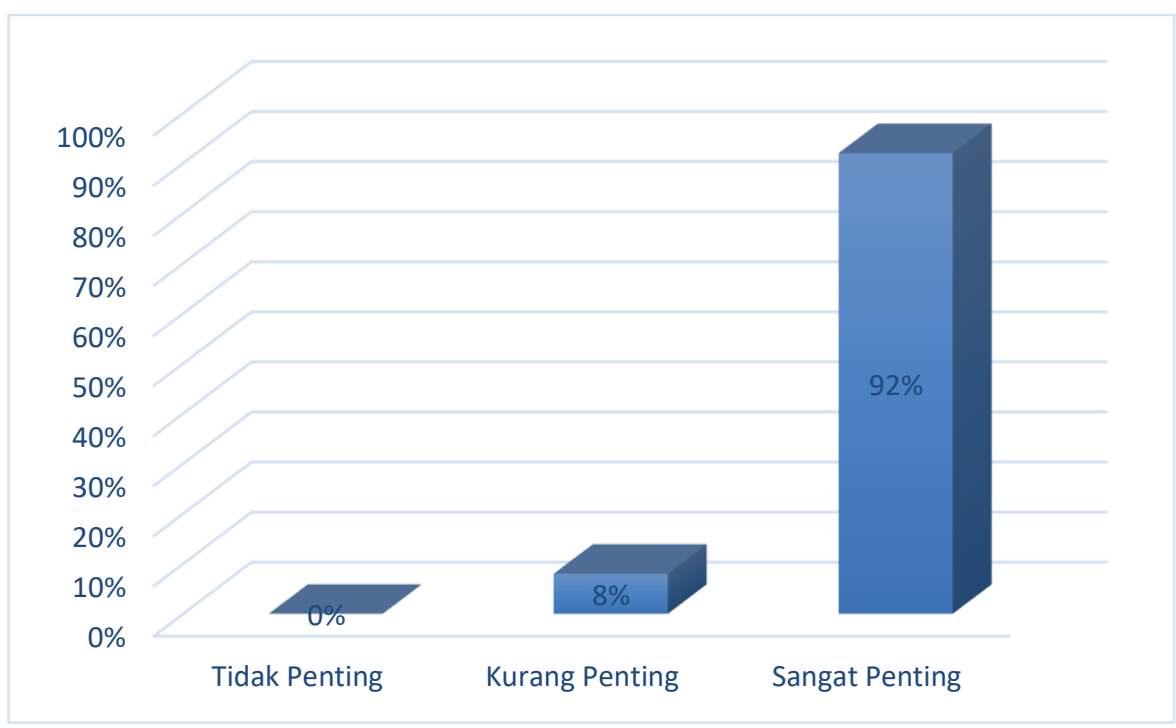

Gambar 4. Presepsi guru terhadap penulisan karya tulis ilmiah

Berdasarkan gambar 4 dapat diketahui bahwa persepsi guru tentang penting atau tidaknya pelatihan menulis mendapatkan hasil yang cukup memuaskan. Sebanyak $92 \%$ peserta menyatakan sangat penting dilakukan pelatihan menulis, sedangkan $8 \%$ menyatakan kurang penting. Setelah persepsi ditanyakan selanjutnya adalah tujuan mengikuti pelatihan. Berikut dapat disajikan tujuan responden dalam mengikuti pelatihan. Setelah rangkaian kegiatan pelatihan dan pendampingan selesai, para guru diberikan angket terkait materi yang telah disampaikan. Tujuannya adalah mengukur sejauh mana peserta memahami materi yang telah 
disampaikan, mengetahui persepsi peserta tentang kegiatan pelatihan dan kemauan menulis para guru setelah diberikan pelatihan. Selain itu penyebaran angket sebagai bahan evaluasi pelaksanaan pengabdian masyarakat. Berikut ini dapat disajikan angket pelatihan dan pendampingan penulisan karya ilmiah.

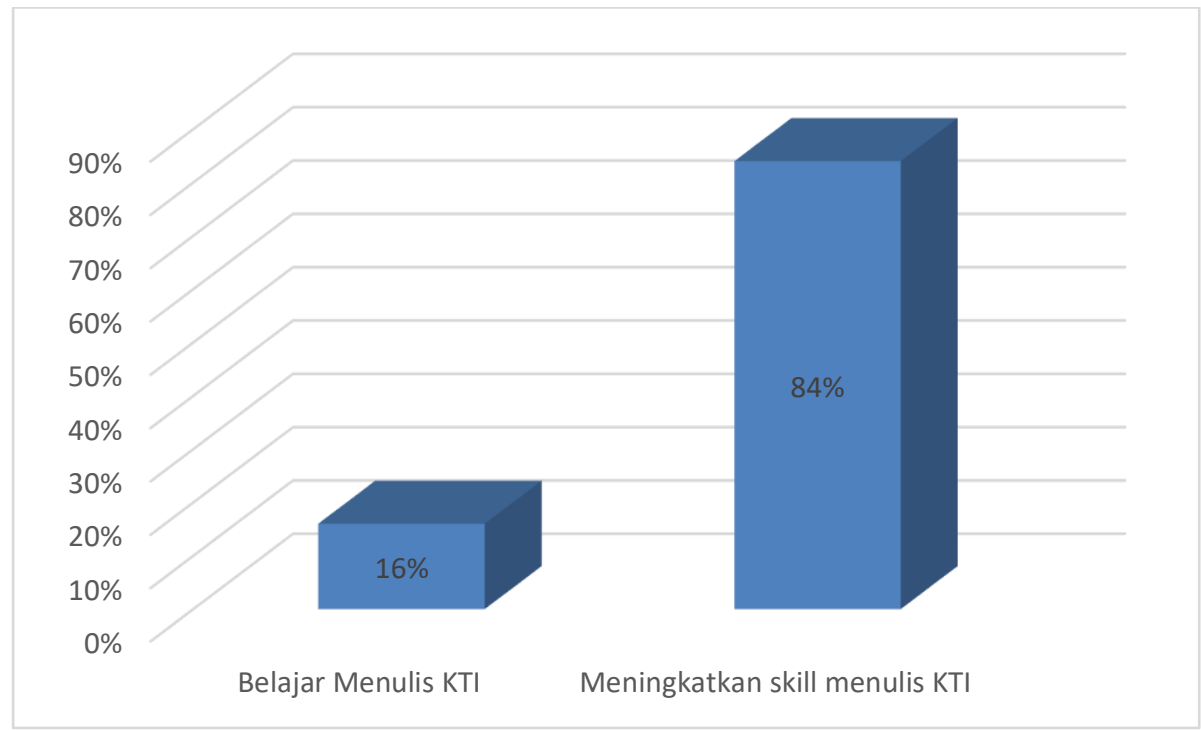

Gambar 5. Tujuan guru mengikuti pelatihan

Pada gambar 5 dapat diketahui bahwa tujuan guru mengikuti pelatihan bervariasi. Setelah dilakukan reduksi data secara garis besar terdapat dua tujuan utama dalam mengikuti pelatihan yaitu belajar menulis dan meningkatkan skill untuk menulis KTI. Sebanyak 84\% responden bertujuan belajar menulis, sedangkan $16 \%$ bertujuan upgrade ilmu tentang menulis. Aspek ketiga yang ditanyakan kepada peserta pelatihan adalah intensitas dalam mengikuti pelatihan yang pernah diikuti. Berikut dapat disajikan intensitas mengikuti pelatihan oleh peserta pelatihan.

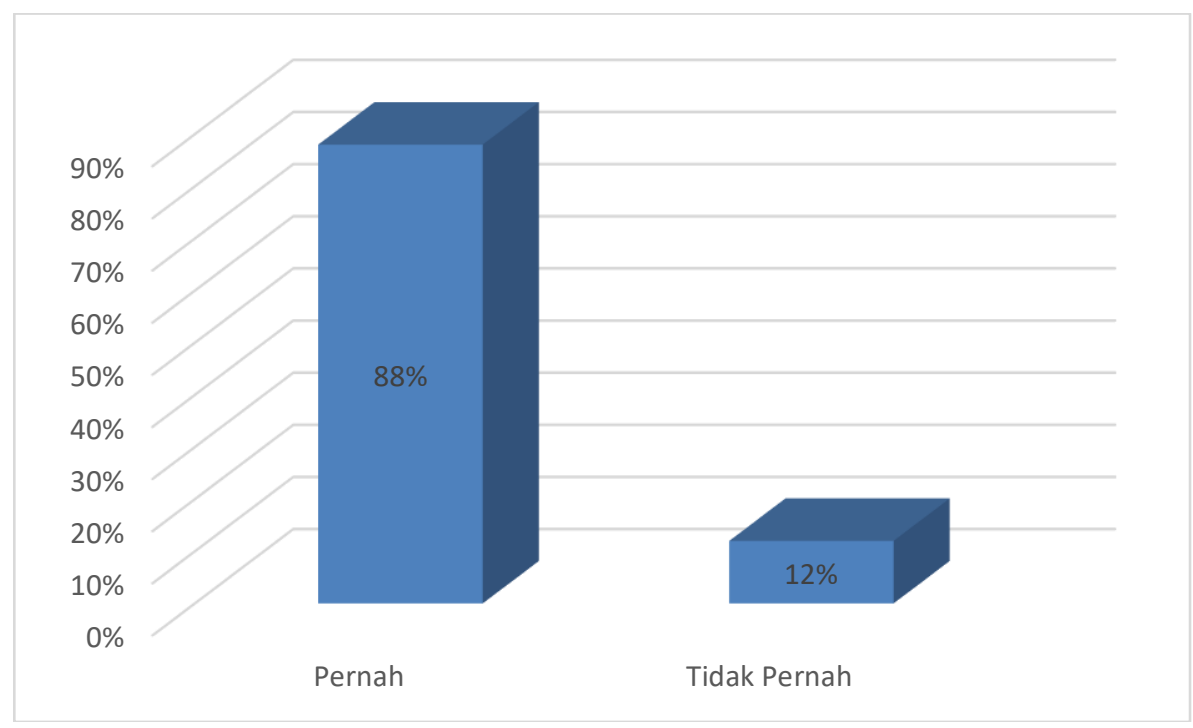

\section{Gambar 6. Keikutsertaan guru dalam pelatihan karya tulis ilmiah}

Berdasarkan gambar 6 dapat diketahui bahwa jumlah guru yang pernah mengikuti pelatihan menulis karya ilmiah sebesar $88 \%$, sedangkan $12 \%$ menyatakan belum pernah. Jumlah guru yang belum pernah mengikuti pelatihan tergolong cukup besar. Idealnya semua guru minimal pernah mengikuti pelatihan menulis agar memiliki kemampuan dalam menulis 
karya ilmiah yang baik. Aspek berikutnya merupakan evaluasi pelaksanaan pelatihan. Para guru diberi pertanyaan terkait dengan penguasaan materi yang telah diterima selama pelatihan.

Secara umum pelaksanaan kegiatan pelatihan dan pendampingan menulis karya ilmiah untuk guru-guru se Indonesia berjalan dengan lancar. Namun demikian terdapat catatan penting sebagai bahan evaluasi. Salah satunya terkait dengan motivasi menulis di kalangan guru. Berdasarkan hasil evaluasi ternyata kemauan menulis setelah dilakukan pelatihan dan pendampingan masih rendah. Guru masih menganggap bahwa menulis itu sulit. Hal ini dapat dipahami mengingat kegiatan menulis merupakan aktivitas yang kompleks. Modal utama untuk menulis adalah membaca (Widodo, Jailani, Novitasari, Sutisna, \& Erfan, 2020). Tanpa membaca kegiatan menulis sulit dilakukan. Membaca sebagai salah satu.

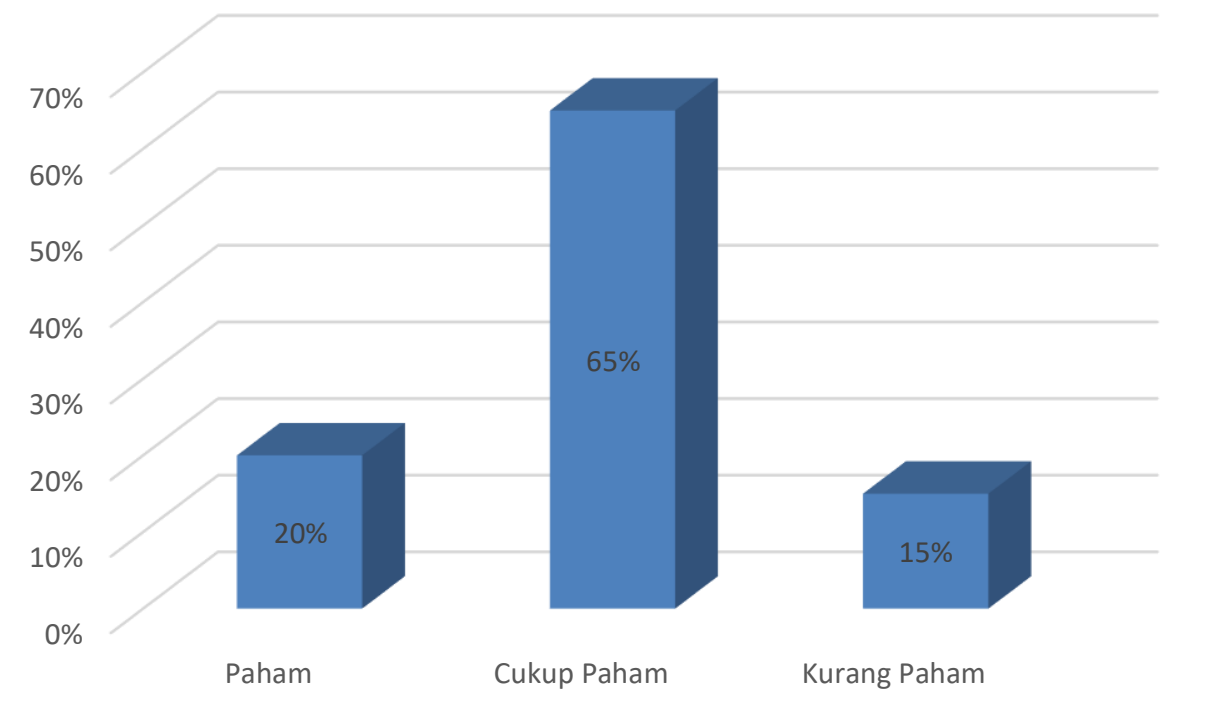

Gambar 7. Pemahaman guru terhadap materi yang telah di sampaikan

Berdasarkan gambar 7 dapat diketahui bahwa jumlah guru yang mengaku paham atau dapat menguasai materi pelatihan dengan baik sebanyak $20 \%$, cukup paham $65 \%$, sedangan sisanya $15 \%$ menyatakan kurang paham. Hal ini menunjukkan bahwa pelaksanaan kegiatan pelatihan cukup berhasil, meskipun terdapat beberapa hal yang harus dibenahi. Aspek terakhir yang dijadikan evaluasi terkait dengan kemauan menulis para guru setelah diberikan pelatihan. Berikut dapat disajikan kemauan menulis para guru setelah diberikan pelatihan. kegiatan literasi berperan sangat vital dalam pengembagan ilmu pengetahuan (Widodo, Indraswati, \& Royana, 2020). Ironisnya kegiatan membaca belum menjadi budaya di kalangan masyarakat (Sobri, Nursaptini, Widodo, \& Sutisna, 2019). Rata-rata minat baca kalangan akademisi sekalipun masih rendah (Gumono, 2016). Maka dari itu sebagai langkah awal untuk menjadi penulis yang baik adalah menjadi pembaca yang baik. Terlebih lagi karena menulis merupakan tuntutan profesi bagi seorang guru (Mujianto et al., 2017). Melalui program pelatihan yang telah dilakukan diharapkan guru dapat memulai untuk menulis karya ilmiah yang sangat berguna untuk kenaikan pangkat guru. Karya ilmiah yang dibuat juga akan berguna untuk keberlangsungan proses pembelajaran yang lebih baik, sehingga dengan adanya tulisan karya ilmiah dari hasil proses pembelajaran sebelumnya akan dijadikan rujukan untuk memperbaiki proses pembelajaran berikutnya agar menjadi proses belajar mengajar yang lebih efektif.

\section{KESIMPULAN}

Secara umum kegiatan pelatihan dan pendampingan dapat berjalan dengan lancar. Kemampuan guru dengan adanya pelatihan dapat meningkat. Namun demikian kemauan menulis di kalangan guru perlu ditingkatkan. Berdasarkan hasil evaluasi pelatihan dan pendampingan penulisan karya ilmiah, dapat diketahui bahwa masih ada peserta yang belum memahami dengan baik terkait dengan penulisan karya ilmiah. Maka dari itu perlu dilakukan 


\section{COMMUNITY : Jurnal Pengabdian Kepada Masyarakat Vol. 1 No. 1 Mei 2021 e-ISSSN : 2797-0159 | p-ISSN : 2797-0574}

kegiatan lanjutan dalam pelatihan dan pendampingan penulisan karya tulis ilmiah terutama berkaitan dengan publikasi. Selain itu perlu juga dilakukan pendekatan kepada para guru mengingat kesadaran dan motivasi dalam menulis masih rendah.

\section{DAFTAR PUSTAKA}

Cahyani, I. (2010). Peningkatan Kemampuan Menulis Makalah Melalui Model Pembelajaran Berbasis Penelitian pada Mata Kuliah Umum Bahasa Indonesia. Sosiohumanika Jurnal Pendidikan Sains Sosial Dan Kemanusiaan,3(2), 175-192.

Ermiana, I., Affandi, L. H., \& Kusuma, A. (2019). Workshop Implementasi Penelitian Tindakan Kelas (PTK) Berbasis Lesson Study (LS) di SD Negeri 15 Cakranegara. Jurnal Pendidikan Dan Pengabdian Masyarakat, 2(1), 6-12.

Gereda, A. (2014). Kemampuan Menulis Deskripsi Mahasiswa Program Studi Pendidikan Bahasa Dan Sastra Indonesia Universitas Musamus. MAGISTRA: Jurnal Keguruan Dan Ilmu Pendidikan, 2(1), 125-137.

Gumono. (2016). Profil minat baca mahasiswa FKIP Universitas Bengkulu. Wacana, 14(1), 65-78.

Mujianto, M., Zubaidi, Z., \& Suprapto YM, Y. (2017). Peningkatan kemampuan menulis karya ilmiah mahasiswa program jaringan telekomunikasi digital ( JTD ) melalui problem based learning. In S. Sukatman, A. Muti'ah, \& A. Taufiq (Eds.), Prosiding Seminar Nasional \#3: Bahasa Dan Sastra Indonesia Dalam Konteks Global (pp. 177-186).

Siregar, A. Z., \& Harahap, N. (2019). Strategi Dan Teknik Penulisan Karya Tulis Ilmiah Dan Publikasi. Yogyakarta: Deepublish.

Sobri, M., Nursaptini, N., Widodo, A., \& Sutisna, D. (2019). Pembentukan karakter disiplin siswa melalui kultur sekolah. Harmoni Sosial: Jurnal Pendidikan IPS, 6(1), 61-71.

Widiastuti, S. (2019). Kemampuan menulis daftar rujukan mahasiswa Program Studi Pendidikan Guru Sekolah Dasar (PGSD) Universitas Islam Balitar (UNISBA). KONSTRUKTIVISME, 11(1), 32-41.

Widodo, A., Indraswasti, D., Erfan, M., Maulyda, M. A., \& Rahmatih, A. N. (2020). Profil minat baca mahasiswa baru PGSD Universitas Mataram. Premiere Educandum: Jurnal Pendidikan Dasar Dan Pembelajaran, 10(1), 34-48.

Widodo, A., Indraswati, D., \& Royana, A. (2020). Analisis Penggunaan Media Gambar Berseri Untuk Meningkatkan Kemampuan Membaca Siswa Disleksia Di Sekolah Dasar. MAGISTRA, 11(1),1-21.

Widodo, A., Jailani, A. K., Novitasari, S., Sutisna, D., \& Erfan, M. (2020). Analisis Kemampuan Menulis Makalah Mahasiswa Baru PGSD Universitas Mataram. Jurnal DIDIKA, VI(1), 77-91. 